\title{
Microform Developments Related to Acquisitions
}

INTRODUCTION

L

$\triangle$ IBRARIES ARE SPENDING an increasing amount of money on acquisitions and an expanding portion of these expenditures is for microforms. The current student enrollment in colleges and universities in this country is estimated to exceed six million. The expansion in area studies programs, as well as in the traditional curricula has contributed to the need for increased resources that is being increasingly met by microforms. Perhaps the most important factor contributing to this trend is the Higher Education Act of 1965 which under Title II, Part A, provides funds for the strengthening of college and research library resources. This authorization includes funds for the purchase of microfilms, microfiche, and micro-opaques, and the volume and variety of microforms being made available have grown apace.

The academic library statistics for 1969/70 published by the Association of Research Libraries (ARL) show that there are a total of $34,410,400$ microform units in the collections of the seventy-six major United States libraries tabulated. The median total microform units per library for $1969 / 70$ was 412,869 units, an increase of 57,379 units over the median figure reported for 1968/69. Even though a microform unit may vary from a single microfiche, Microcard or Microprint to a full roll

Robert C. Sullivan is chief, Order Division, Library of Congress. of microfilm, an average increase of 57,000 units per year for the larger research libraries represents an impressive volume of microform acquisitions. The largest total number of microform units held was reported by Syracuse University library with a collection consisting of 22,449 reels of microfilm, 203,276 Microcards, 690,678 Microprint sheets and 271,360 microfiche. Boston University library reported 98,598 units, the smallest total number of microform units held; this figure includes $\mathbf{5 , 9 2 0}$ reels of microfilm. ${ }^{1}$

The most widely publicized development in library microforms in recent years has been the microfiche, particularly the ultramicrofiche (UMF). The traditional $35 \mathrm{~mm}$ roll microfilm, the dominant microform for library consumption for approximately the twentyfive year period between the late '30s and the early ' 60 s, has now been upstaged by the microfiche, usually in the 4 "x6" film transparency size. Currently, $16 \mathrm{~mm}$ roll microfilm is gaining somewhat in popularity, especially in cartridge format in special libraries. Much has been written, particularly in the data processing journals, about the promise of computer output microfilm (COM). At the same time, micropublishing is flourishing with many new firms offering an expanding variety of materials in microform to libraries and educational institutions. For several years, the federal government, through the Office of Education, has been funding microform research, a most welcome and healthy development. Fortunately, 
publications about microforms are more numerous than ever before. All of these trends constitute significant developments in the area of library microforms. It behooves the acquisitions librarian to be aware of these changes and to try to interpret them to assist in the acquisition of microforms for his particular library.

\section{MicROFICHE}

To define our terms, the word "microform" refers mainly to roll microfilm, Microcard, Microprint, and microfiche. To maintain perspective, it should be recognized that there is no one single microform process, size, or format that is best suited for all situations. Each microform has peculiar advantages and disadvantages and should be judged on its merits based on the type of material filmed and the use made of it in a particular situation. One index of the maturity of the microform industry is that these advantages and disadvantages are now well publicized and generally acknowledged. The annual Guide to $\mathrm{Mi}$ croforms in Print, lists these factors to assist the buyer in choosing from the variety of microforms available. ${ }^{2}$ Generally speaking, roll film is preferred for browsing for material such as a newspaper file. Roll microfilm $(35 \mathrm{~mm}$ at a modest reduction) is best where archival preservation is the primary goal. The unitized format of the Microcard, Microprint, or microfiche lends itself to more direct reference and to situations where mass dissemination is the primary aim. The unitized microform is essentially utilized as a publishing medium rather than a means of preservation.

The ascendancy of microfiche is due largely to its adoption by the federal government for the dissemination of scientific and technical reports by agencies such as AEC, NASA DOD, Department of Commerce (NTIS) and OE. These fiche conform to COSATI specifications in that they are $4^{\prime \prime} \times 6^{\prime \prime}$ in over- all size and employ an 18X-20X reduction. Under the OE ERIC Program alone more than one million microfiche are now disseminated each month. Leasco Inc. has the current contract to produce these microfiche for OE. Librarians may be more familiar with the many advertisements by Encyclopaedia Britannica for their ultramicrofiche (UMF) or "Microbook" process, or with the National Cash Register Company (NCR) advertisements for their Photo-chromic-micro-image (PCMI) process. These processes are different in technical detail but it will suffice to note that the EB fiche is 3" $\mathrm{x} 5$ " in overall size, the image is reproduced on the fiche at a $55 \mathrm{X}$ to $90 \mathrm{X}$ reduction, and approximately 90 percent of the titles are filmed on a single fiche. The NCR fiche is $4^{\prime \prime} \mathrm{x} 6^{\prime \prime}$ in overall size at $100 \mathrm{X}$ to $150 \mathrm{X}$ reduction, with an average of seven to ten titles per fiche. The bonus to libraries, no matter which of these UMF processes is chosen, is that they have demonstrated the degree to which bibliographical control can and should be made available with microform projects. LC cards are to be provided to subscribers to these series, as well as printed indexes of the contents of each series offered. Thus, a valuable precedent has been set, and librarians should demand this type of complete systems approach to all future micropublishing projects.

\section{CARTRIDGE MicrofiLM}

Roll microfilm in cartridges or cassettes is increasing in popularity because of the obvious convenience it offers in avoiding the threading of microfilm reading machines, the scanning speed possible in motorized readers, and the attractiveness of using it with readerprinters. Both $35 \mathrm{~mm}$ and $16 \mathrm{~mm}$ cartridges are available, but the $16 \mathrm{~mm}$ size is more popular because the equipment to utilize it was developed earlier, promoted more widely, and the economy of 
the smaller-sized film is attractive. Problems militating against the more widespread use of this medium, in addition to the competition offered by other formats, are the relatively higher reduction ratios necessary and the nonstandardization of the cartridges. The U.S. Army is working on a microfilm container standardization project to make the presently most popular containers, of Eastman Kodak, the 3M Company, and Bell \& Howell, compatible. ${ }^{3}$ The most popular applications for $16 \mathrm{~mm}$ cartridge microfilm have been the microfilming of library card catalogs and back files of scientific and technical periodicals. Libraries of such diverse sizes as Pennsylvania State University and El Centro College have distributed computer-output-microfilm of their card catalogs in $16 \mathrm{~mm}$ cartridges to numerous locations on their campuses to assist faculty and student access, as well as to expedite book ordering.

\section{Computer Output MicrofiLm}

Computer-Output-Microfilm has received a great deal of publicity in recent years. Although it has had some spectacular applications in business and industry, its impact on the library world has been minimal to date. Like library automation, its actual practical application in libraries is apt to be painfully slow and expensive. The COM technology is undergoing a process of gradual refinement and evolution rather than revolution. A computer microfilm information system is not suitable in a situation where the data base changes rapidly or where user interaction with the data base is required. Just as was the case about ten years ago when a growing number of computer installations gave birth to numerous data processing service companies, we have witnessed a rapid growth in the number of firms offering $\mathrm{COM}$ equipment and services. However, this field is suffering acute growing pains with the competition intense, as evidenced by the number of firms that have recently dropped by the wayside, have been gobbled up in corporate mergers, or have severely curtailed their services.

A successful application of COM for student records control is in operation at the University of Wisconsin, Milwaukee campus; it employs a Chicagobased COM service bureau to produce $4^{\prime \prime} \times 6^{\prime \prime}$ microfiche. These listings of students and their schedules are updated by-weekly in various sequences and formats and are supplied to more than twenty campus locations. Similar applications have been reported in use at Temple University, the University of California at Santa Cruz, the University of Missouri, and the University of Washington. The University of Colorado library at Boulder employs a COM service bureau in Denver to produce a weekly update of its process file which records the status of all materials on order. This film is supplied in $16 \mathrm{~mm}$ cartridges which can be employed with a reader-printer if a hardcopy reproduction of any order slip is required. COM applications are increasing in number but the technology suffers seriously from lack of standardization. As is unfortunately the case with much microform equipment, one COM device or system is not compatible with another, much less with existing microform equipment generally found in libraries. Librarians should approach COM with cautious optimism and only after careful analysis of all options possible and evaluation of all of the cost factors involved.

\section{MicROPUBLISHING}

Micropublishing is flourishing, as is amply evidenced by the volume and variety of advertisements in library literature. The Department of Commerce published a pamphlet in 1969 entitled Microforms: A Growth Industry which estimated current micropublishing sales 
volume in this country to be $\$ 25$ million a year, with a 10 percent to 15 percent annual increase predicted. ${ }^{4} \mathrm{~EB}$ alone is reported to have invested more than $\$ 6$ million in launching its first "Microbook" series entitled The Library of American Civilization. As an indication of the growth of the industry in recent years, NCR acquired the Microcard Corporation and launched its own UMF (PCMI) series on American Civilization. The Bell \& Howell Company acquired the firm of Micro-Photo and relocated it in Wooster, Ohio. The Xerox Corporation acquired University Microfilms of Ann Arbor, Michigan, and more recently the New York Times acquired the Microfilming Corporation of America. Reprint publishers such as Greenwood Publishing Corporation and AMS Press have created microform divisions. The 3M Company, IM Press has a contract with New York Public Library and NCR's Micro Photo Division has a contract with the Newberry Library in Chicago. New firms and new services are offered with each passing month.

The expanded utilization of microforms in the federal government continues with the applications at the Social Security Administration, Census Bureau, and the Patent Office being prime examples. Most newsworthy perhaps is the announcement late in 1970 by A. N. Spence, the Public Printer, that the Government Printing Office is exploring the possibilities for converting all publications listed in the GOP Monthly Catalog to microform. The potential impact of converting such a large number of publications to microform, particularly on depository libraries, is sizeable. The information available thus far suggests that microfiche at a $48 \mathrm{X}$ reduction is receiving favorable consideration. However, all that is known for certain is that GPO will actively investigate the adoption of some microform program in the near future. The technical and bibliographical standards agreed upon for such a program could help stabilize the present chaotic situation where a multitude of microform formats and reduction ratios are employed. Several standards very likely will have to be accepted because of the variations in the sizes and styles of government publications.

Allen Veaner's chapter on micropublication in Volume 2 of the Advances in Librarianship Series gives particular attention to the problems of acquiring, controlling, and servicing microtexts in libraries. This survey of the state-ofthe-art of micropublishing provides excellent background information for the acquisitions librarian. ${ }^{5}$

\section{Cooperative Projects}

The most noteworthy cooperative microform projects are those operated under Association of Research Libraries (ARL) sponsorship such as the Foreign Newspaper Microfilm Project, the Center for Chinese Research Materials, and the Slavic Bibliographic and Documentation Center. The Foreign Newspaper Microfilm Project is operated by the Center for Research Libraries (CRL) with most of the actual filming being done at the University of Chicago library photoduplication department; its purpose is to subscribe to a list of more than 100 top priority foreign newspapers that are not regularly available from reliable sources, commercial or noncommercial, to regularly film them, and to sell positive prints to subscribing libraries as economically as possible. Participants in the project pay an annual membership fee in addition to a flat rate for each foot of positive microfilm supplied. ${ }^{6}$

The Chinese and the Slavic Centers are located at ARL headquarters in Washington, D.C.: their purpose is to collect and disseminate information on fugitive Chinese and Slavic research publications, including a limited num- 
ber of photoreproduction and reprinting projects.

The ARL was also instrumental in establishing the Official Gazettes Microfilming Program at the New York Public Library (NYPL) in 1958. In cooperation with the United Nations Library, NYPL regularly films the national and local official gazettes of foreign countries; a list of more than 300 gazettes filmed, generally from 1958 to date, is published by NYPL. An exception to the NYPL project is that the official national and local government gazettes of India, Pakistan, Ceylon, and Nepal are filmed in New Delhi for the Library of Congress. ${ }^{\circ}$

Additional cooperative microform projects sponsored by CRL are the Cooperative African Microform Project (CAMP) and the South Asian Microform Project (SAMP). CAMP was formed in 1963, as a result of discussions in meetings of the African Studies Association, to acquire microforms of Africana selected by the sixteen participants in this country, Canada, France, and Africa. SAMP was developed in 1967 at the request of members of the Association of Asian Studies; its purpose is to create and maintain, for the common use of the subscribing libraries, a readily accessible collection of back-files of nineteenth and twentieth century newspapers, periodicals, and documents relating to South Asia that are unobtainable in this country. Each library subscribing to this project pays an annual subscription fee based on the size of its book budget.

\section{RESEARCH}

More than three-quarters of a million dollars has been provided by the Office of Education ( $\mathrm{OE}$ ) to underwrite research relating to library microforms in

\footnotetext{
- Details regarding the availability of these more than forty titles may be secured from the Library of Congress photoduplication service.
}

the past four years. The major research projects undertaken, some portions of which are still in progress, have been the following:

\section{Association of Research Libraries (ARL)}

The original grant to ARL for FY 1969 was for a Determination of User Needs and Future Requirements for a Systems Approach to Microform Technology, with Donald C. Holmes as principal investigator. The report for this initial project in the summer of 1969 contained nine recommendations for further study. ${ }^{7}$ Funding for this project was continued into FY 1970 but the mission was divided into two parts: Part I, with Donald C. Holmes as principal investigator, was for a Determination of the Environmental Conditions Required in a Library for the Effective Utilization of Microforms. ${ }^{8}$ Part II, with Felix Reichmann as the investigator, was devoted to the Determination of an Effective System of Bibliographic Control of Microform Publications. ${ }^{9}$ Again, the funding to ARL was renewed and for FY 1971 the project is continuing in two parts: Part I, with Edward Miller as the investigator, is pursuing Holmes' first recommendation in the initial report that a permanent, national microform organization or agency be established; Part II continues the Reichmann study to make final recommendations for the bibliographic control of microform publications on the local, national, and international levels. Establishment of a national microform agency to promote and police standards would be a great boon to libraries and we hope that this recommendation can be implemented soon. One of the recommendations in Reichmann's preliminary report is that published papers should urge library administrators to assign adequate manpower to the processing and servicing of microforms. I would add emphasis to the word "adequate." 


\section{Denver Research Institute (DRI)}

The original grant to DRI at the University of Denver, also for FY 1969, authorized a study of the Characteristics of Ultramicrofiche and Their Application to Colleges and Universities, to be conducted by James P. Kottenstette..$^{10}$ One of the five major conclusions reached was that UMF is economically attractive for the creation of "core" library collections and can be utilized to create information systems of great value to the student. Another finding was that no "best" reduction ratio can be identified for the UMF, either on a cost or operational basis, and that it is the responsibility of the market place to judge the system that responds best to particular needs in education. Funding for this project was authorized for FY 1970 for a study entitled An Investigation of the Environment for Educational Microform Utilization, this segment of the research was subdivided into classroom studies and a carrel design study. ${ }^{11}$ Preliminary findings showed that students prefer to be able to adjust the angle of the reading screen on a microform reader and to be able to adjust their own reading position, just as they would if they were reading a hard copy book. Also, it was found that students better tolerate microforms and associated equipment if the material to be viewed on film is assigned or required reading rather than review or leisure reading. This project culminated at the University of Denver Conference on Microform Utilization in the Academic Library Environment which was held on December 7-9, 1970. One recommendation of the conference was that greater consideration be given by microform equipment manufacturers to the needs and comfort of the user. Another recommendation was that libraries fully support the LC National Register of Microform Masters to promote bibliographic control of microforms and that micropublishers be urged to provide full bibliographical control with their future microform projects. ${ }^{12}$

\section{American Association of Junior Colleges (AAJC)}

Phase I of this four phase project was launched in March 1969 for a study entitled Determination of Student Acceptability and Learning Effectiveness of Microform Collections in Community Junior Colleges. ${ }^{13}$ Bibliographies were compiled for courses in Art appreciation, Black studies, Economics, English, Life science, Mathematics, Nursing, Political science, Psychology, and Spanish. A research design was devel. oped to measure the acceptability and effectiveness of microform collections for courses common to junior colleges. Phase II for 1970/71 consisted of several pilot studies in junior colleges in the Washington, D.C. area. Phase III for 1971/73 will consist of a two-year field test and Phase IV for 1973/74 will include the analysis, reporting, and interpretation of the data collected throughout the study. The findings of this study will most likely provide a further stimulus to the micropublishing industry which in turn will expand the statistics on the acquisition of microforms in libraries.

\section{Publications: Basic Collection}

Essential to the effective performance of any library technical service unit is the assembly and intelligent utilization of a basic reference collection and the tools of the trade. For microforms these reference tools are not as plentiful nor as comprehensive as one would like, but fortunately the choice is widening. The literature of microreproduction for the years 1950 through 1955 is documented in a bibliography compiled by Lester $\mathrm{K}$. Born which appeared in American Documentation, similar literature for the years 1956 through 1966 appeared in Special Libraries in a series of bibliog- 
raphies compiled by Loretta J. Keirsky. ${ }^{14,15}$ This literature is predominantly commercially or technically oriented rather than bibliographically or library oriented. Surprisingly little has been written on microforms from the point of view of the acquisitions librarian.

The most valuable general background articles are contained in the following issues of Library Trends: The April 1955 issue devoted to current acquisition trends in American libraries, the January 1960 issue devoted to photoduplication in libraries, and the January 1970 issue devoted to the problems of acquisition for research libraries. ${ }^{16,17,18}$ Roma Gregory's article on the acquisition of microforms in the latter issue of Library Trends is the most current and relevant article on this subject. A very helpful article by Albert Diaz on what is available in microform and where to find it appeared in the Spring 1967 issue of Library Resources and Technical Services. ${ }^{19}$

To keep abreast of developments relating to library microforms, the annual review articles in LRTS that have appeared since 1957 should be consulted. ${ }^{20}$ The bibliographies that appear at the end of these articles since 1967 are especially valuable since the Keirsky bibliographies cited earlier only extend through the year 1966. It is encouraging that the ERIC Clearinghouse for $\mathrm{Li}$ brary and Information Science has promised to investigate the possibility of continuing these bibliographies on the reproduction of documentary information through 1971 and publishing them annually in the future.

In addition to Library Resources and Technical Services, articles on microforms appear frequently in most of the library periodicals such as College b Research Libraries, Special Libraries, American Libraries, ASIS Journal, Publisher's Weekly, Unesco Bulletin for Libraries, Wilson Library Bulletin, etc. The advertisements for microforms in these journals are particularly informative with regard to new acquisition sources. Specialized library journals frequently contain articles of interest. For example, the February 1970 issue of Law Library Journal contains a good article entitled "Acquisition of Microforms in Law Libraries." 21

Micrographics Weekly, which commenced publication in mid-1970, has emerged as a significant source of prompt information about the microform industry and micropublishing. ${ }^{22}$ It reviews new developments and evidences the awareness of the interest of libraries and educational institutions in microforms. The monthly Information and Records Management periodical also contains a wealth of information on microfilm and its applications. ${ }^{23}$

Obviously, membership in the American Library Association, Resources and Technical Services Division, Reproduction of Library Materials and/or Acquisitions Sections, and participation in their activities is a primary means of keeping informed. The same is true of the Special Libraries Association and the American Society for Information Science, if the membership dues can be mustered. Next on the priority list of memberships is the National Microfilm Association (NMA). Included in NMA membership are subscriptions to the bimonthly The Journal of Micrograph$i c s,{ }^{24}$ the monthly Micro-News Bulle$\mathrm{tin}^{25}$ the quarterly International Micrographic Congress Journal, ${ }^{26}$ and the annual Proceedings of the NMA Conventions. ${ }^{24-27}$ Increasing appreciation of the library and education market is being reflected in the content of these NMA publications; acquisitions librarians will labor under a handicap if they do not have access to this NMA literature to facilitate an understanding of the micrographics industry. For example, the January 1971 issue of The Journal of Micrographics featured a series of articles on microform utilization in libraries and ed- 
ucational institutions. NMA also publishes a valuable reference tool for an understanding of the equipment available for the utilization of microforms in Hubbard Ballou's Guide to Microreproduction Equipment (1968), which is now in its fourth edition. ${ }^{28}$ The 1970 supplement to the Guide lists over 137 new pieces of equipment in 250 pages. $^{29} \mathrm{~A}$ companion volume, also available from NMA, is the International Directory of Micrographic Equipment (1967). ${ }^{30}$ The NMA Glossary of Microfilm Terms is also a helpful reference tool for interpreting offers from and drafting correspondence to micropublishers or other sources of microforms. ${ }^{31}$

A reference tool that is essential for inclusion in the ready reference collection of every acquisitions librarian is ALA's Copying Methods Manual (1966). ${ }^{32}$ This is an invaluable source for gaining an understanding of the various photographic processes, methods, and techniques, and contains a wealth of information relevant to the acquisition of photo reproductions by libraries. The relevance and utility of this manual is no accident since the author was at one time the head of the Photoduplication Service at the University of California Library and Berkeley and has authored countless reports for ALA's Library Technology Program. The bi-monthly Library Technology Reports are also a valuable source of information about new microform equipment services and related products. ${ }^{33}$ The acquisitions librarian cannot intelligently discharge his other responsibilities without an understanding of the equipment to be employed in servicing the microforms acquired.

\section{SEARCHING-BIBLIOGRAPHICAL CONTROL}

The above suggestions for a basic reference collection for maintaining current awareness will not equip the acquisitions librarian for the necessary nego- tiations or the preparation of requests and orders. After the general background literature has been assembled and digested, the librarian must determine what material is needed and/or available for acquisition, or decide where to acquire what has already been recommended for acquisition. Unfortunately, the bibliographical control of microforms has not received the attention and support it deserves. The proliferation of microforms produced and acquired by libraries has far outstripped the capacity of libraries to catalog and record their location internally, much less to report holdings to a central source.

The need expressed in the series of articles in the January 1960 issue of $L i$ brary Trends, devoted to photoduplication in libraries, for a Microforms in Print catalog no doubt encouraged the publication the following year of the first issue of the Guide to Microforms in Print. This bibliography is described by the publisher as an "annual cumulative guide, in alphabetic order, to books, journals, and other materials, which are available on microfilm and other microforms from United States publishers. Theses and dissertations are not listed. The Guide lists the offerings of fiftysix micropublishers and contains more than 18,000 titles; some of these entries are for entire collections but the majority are for newspapers and periodicals. A companion volume Subject Guide to Microforms in Print lists the same entries under broad subject classifications. ${ }^{34}$

The pleas and planning of the library community for bibliographical control of the rapidly mounting number of microforms, best illustrated by the 1960 Library Trends article by Schwegmann, culminated in 1965 in a grant by the Council on Library Resources Inc. to the Library of Congress to establish the National Register of Microform Masters (NRMM) ${ }^{35}$ As indicated in the 
introduction: "The Register has two basic purposes. One is to provide a complete national register of microform masters from which libraries may acquire prints when needed and thus avoid the expense of unnecessarily making another master. The other purpose is to help libraries assure the preservation of our intellectual heritage by identifying those microform masters that meet the requirements for such preservation." The Register is concerned only with master copies, which are defined as those which are held solely for the purpose of making further copies. For the purposes envisioned by the Register, single copies from the master must be made available at any time and for a reasonable fee. The Register also includes a second category of masters which, in addition to meeting the foregoing requirements, are housed in temperature controlled, fireproof space and are owned by a responsible, nonprofit institution. The Register includes foreign and domestic books, pamphlets, serials, and foreign doctoral dissertations; it does not include newspapers, technical reports, typescript translations, foreign or domestic archival manuscript collections, or U.S. doctoral dissertations or master's theses.

The first issues of the published Register, uniform in format with the other Library of Congress catalogs and provided free to subscribers to the National Union Catalog, were published in September 1965 and January 1966. Annual cumulations have been published for 1966 through 1969. The 1969 issue of the Register contains only serials listed alphabetically by main entry; it does not supersede the 1966-1968 issues which are to be used to locate entries for monographs. It supersedes and cumulates the more than 14,000 entries for serials included in all previous issues.

Fuller descriptions of the NRMM are contained in articles by Applebaum and Blum. ${ }^{36,37}$ The fact that the Register is a union list which emphasizes the "master" preservation negatives in libraries and excludes newspapers distinguishes it from the Guide. Libraries are urged to report holdings of master negatives to make the NRMM as complete as possible. The need for such complete reporting was recognized by both the Reichmann study and the Denver Conference mentioned earlier.

Since the NRMM editions do not include any of the newspaper entries listed in the sixth edition (1967) of Newspapers on Microfilm (NOM), now published by the Catalog Publication Division of the Library of Congress, librarians should continue to consult NOM to search for U.S. holdings of microfilm of domestic and foreign newspapers. ${ }^{38}$ Reference should also be made to the Microfilm Clearinghouse Bulletin for which eighty-six numbers have been issued since 1951 as supplements to the Library of Congress Information Bulletin. ${ }^{39}$ Another source for microforms is the series of approximately 180 announcements of research materials filmed at the Library of Congress since 1965; these circulars are available from the Photoduplication Service of LC.

Many microform projects combine the copying of published and unpublished documents. The Center for the Coordination of Foreign Manuscript Copying, formerly located in the Manuscript Division of the Library of Congress, was established in 1965 to coordinate photocopying projects conducted in foreign archives and libraries by American institutions and individuals to avoid duplication of effort and expense through cooperative planning. Further purposes of the center were to record the location of copies of foreign collections in this country, in the National Union Catalog of Manuscript Collections, eight volumes of which (describing 25,145 collections) have been published since 1962, and to disseminate information to the scholarly community. ${ }^{40}$ 
Beginning in the spring of 1967 , the center published seven reports which appeared as semiannual issues of News From the Center. ${ }^{41}$ These issues of the News included lists of recently complete photocopying projects and bibliographical lists relating to foreign manuscript collections in the United States and to manuscript collections in Western Europe, Asia, the Pacific area, France, and Latin America. The center has now been closed, but answers to questions in this area, or copies of issues of the News, can be obtained from the Manuscript Division, Library of Congress.

The 1967 Diaz article, referred to earlier, also relates the first attempt to list microfilms by the publication in 1942 of the Union List of Microfilms, with a cumulative edition in 1951 and a supplementary and final cumulation for 1949-1959 published in 1961.42 A Union List of Publications in Opaque Microform also was published in 1959, with a 1961 supplement and a 1965 revised edition. ${ }^{43}$ These volumes of the various versions of a Union List, together with the Guide, NOM and NRMM, are essential reference tools for searching to determine availability of publications in microform. The Union List volumes exclude newspapers, dissertations, and a number of specialized series.

In addition to searching the standard bibliographies already cited and scanning the currently published journals for advertisements and announcements, the obvious approach to discovering new micropublications is to write to all micropublishers and ask to be added to their mailing list to receive all catalogs and announcements. Some of the major micropublishers such as University Microfilms and Micro Photo publish newsletters which are helpful in keeping posted on what is available and what is planned. The best single source of names and addresses of micropublishers is contained in the Guide to Microforms in Print. However, this list is not exhaustive and should be supplemented by names and addresses identified in scanning the literature.

Frequently overlooked sources for library microforms are the numerous libraries listed in the Directory of Institutional Photocopying Services compiled by Cosby Brinkley. ${ }^{44}$ Librarians all too often equate microforms with commercial producers and neglect library producers. The Directory is now in its fourth edition and lists 151 libraries with "significant facilities" for photocopying. Many of the libraries listed have sizeable stores of master negative microfilms from which positive copies can be purchased at reasonable rates.

Librarians have to decide whether to purchase a copy of an existing microform or to order one prepared to their specifications. Obviously, it is much less expensive to purchase a print from an existing microform, when the cost of the master negative has already been paid, than to pay the full cost of preparing the negative. Service is also much faster when only a print needs to be made from an existing negative.

If an order is to be directed to one of the libraries listed in the Directory, a search should first be made to determine whether the library holds the original of the item required. This is increasingly more possible with the publication of the printed volumes of the National Union Catalog, Pre-1956 Imprints. ${ }^{45}$ A total of 124 volumes have been published to date, covering the alphabet to "Counihan," with the exception of volume 53-56, which have been reserved for Bible entries and will be published later. Editing of the letter " $\mathrm{E}$ " has been completed, representing more than a fourth of the total catalog.

Free cost estimates for photocopying are available from many libraries. For instance, the Library of Congress provides this service; it holds an extensive collection of master negative microfilm and is adding more than 8,000 reels each 
year to this collection. Other large stores of master negative microfilm are contained in the holdings of the New York Public Library, the University of Chicago library, and the Hoover Institution.

Examination of prospectuses and announcements should be made with great care to determine whether the microform advertised is actually available. Unfortunately, some advertisements still appear that do not state when the microforms will be completed and actual delivery will be made. To avoid the pitfall of encumbering funds that might lapse, careful inquiry should be made to determine whether the master negative microform exists and what the delivery schedule is for distribution copies.

Announcements should be scanned to determine such vital factors as the film format or internal and external dimensions of the microform, the reduction ratio and position of the images, the polarity (negative or positive), generation (whether printed directly from a master negative), and film stock (whether silver emulsion, diazo, or vesicular film). Preferably, samples should be obtained for examination prior to ordering. If possible, a cost quotation should be secured before an actual order is issued. If a cost estimate is made, care should be taken to provide for added costs such as reels and boxes, mailing, minimum charges per item or order, special handling, etc. It is particularly important to determine before an order is issued whether the file filmed was complete. If possible, a list of any missing or mutilated issues should be secured to permit evaluation of the bibliographical integrity of the filmed file. It also should be determined whether the material filmed was tightly bound resulting in any loss or distortion of text in the gutters of the spines of the volumes. The availability of printed cards and/or of published indexes, lists, or guides to the material filmed should also be determined. Added items to ascertain are whether returns are acceptable and what payment schedule is permissible.

Standards that should be included in the acquisitions librarians ready reference collection and which may be cited in the specification of order include ALA's Microfilm Norms, Specifications for Library of Congress Microfilming, the (COSATI) Federal Microfiche Standards, and NNSI's Specifications for Microfiches (PH5.9).46-49 These publications refer to ANSI, NMA, and other photographic standards.

\section{ORDERING}

Standard library purchase requisition or request forms are insufficient for microforms; the specifications of order should be complete and precise in detail to avoid misunderstanding. Not only should the bibliographical citation be complete, but the order should specify such vital factors as the format, reduction, position, polarity, generation, film stock, background or integrated density, and hypo residue. Libraries should take care to develop their own general specifications for acquiring microforms or should specify that the microform conform to Microform Norms, Specifications for Library of Congress Microfilming or other published specifications. Any special targets required should be clearly explained and preferably should be supplied with the order. If the film ordered is to be spliced into existing film, the order should state the spacing needed on the film between nonconsecutive issues, etc. If the film is to be utilized for Xerox Copyflo printing then the order should clearly state this requirement. How should microforms be ordered? Carefully.

\section{ACCESSIONING}

The need for the inspection of delivered microforms is frequently ignored or given too little attention in li- 
braries. If the specifications of order are carefully defined then the determination of whether the product delivered actually conforms to these specifications should be equally detailed. Fortunately, librarians now have a detailed guide to follow in performing this evaluation. The Library Technology Program has published The Evaluation of Micropublications: A Handbook for Librarians by Allen B. Veaner. ${ }^{50}$ The Veaner handbook is based on an article in the June 1968 issue of the ACRL book review publication CHOICE entitled "The Crisis in Micropublication," as well as two additional articles later the same year. With the support of ALA's Library Technology Program, and uti- lizing the procedures set forth in the Handbook, the editorial board of CHOICE has agreed to cooperate with the Micropublishing Subcommittee of ALA in regularly publishing reviews of micropublishing projects, just as is now done for books. These reviews, to be published in CHOICE, will be invaluable to acquisitions librarians in making intelligent selections of micropublications. Sections of the handbook are devoted to the micropublishing industry and procedures for the evaluation of micropublications on the basis of bibliographical, administrative, and technical criteria. An excellent bibliography appears at the end of this indispensable work.

\section{REFERENCES}

1. Association of Research Libraries, Academic Library Statistics 1969/70 (Washington, D. C.: ARL, 1970), 17 p.

2. Guide to Microforms in Print, 1970 (Washington: NCR-Microcard Editions, 1970), $113 \mathrm{p}$.

3. U. S. Army Munitions Command (Picatinny Arsenal, Dover, New Jersey: EDS\&R Project, Interim Reports. 1970).

4. U. S. Department of Commerce, Business and Defense Services Administration, Microforms: A Growth Industry (Washington: GPO, 1969), 18 p.

5. Allen B. Veaner, "Micropublication," in volume 2 of Advances in Librarianship, (New York: Academic Press, 1971), (In press).

6. The Center for Research Libraries, Foreign Newspaper Microfilm Project, Circular Letter No. 21 (Chicago: Feb. 1971), 3 p.

7. Donald C. Holmes, Determination of User Needs and Future Requirements for $a$ Systems Approach to Microform Technology (Washington: U. S. Office of Education, 1969), 35 p. (Interim Report; ED029-168).

8. - Determination of the Environmental Conditions Required in a $\mathrm{Li}$ brary for the Effective Utilization of Microforms (Washington: ARL, Nov. 1970), p. 1-44. (Part I of an Interim Report submitted to OE).

9. Felix Reichmann, and Josephine M. Tharpe, Determination of an Effective System of Bibliographical Control of Microform Pub- lications (Washington: ARL, Nov. 1970), p. 45-90. (Part II of an Interim Report submitted to OE.)

10. James P. Kottenstette, Study of the Characteristics of Ultramicrofiche and Its Application to Colleges and Universities (Denver: University of Denver, 1969), (Final Report; ED032-447).

11. - Student Learning Characteristics: Comparing Skill Levels Demonstrated on Hardcopy and Microform Presentation (Denver: University of Denver, 1970), (Interim Report).

12. National Register of Microform Masters, 1969, (Washington: Library of Congress, 1970), $183 \mathrm{p}$.

13. Louise Giles, A Research Project to Determine the Student Acceptability and Learning Effectiveness of Microform Collections in Community Colleges: Phase I (Washington: OE, June 1970), 244 p.

14. Lester K. Born, "The Literature of Microreproduction, 1950-1955." American Documentation 7:3 (July 1956), p. 167-87.

15. Loretta J. Kiersky, "Bibliography on Reproduction of Documentary Information, 1955-1966," Special Libraries Spring issues.

16. "Current Acquisitions Trends in American Libraries." Library Trends 3:4 (April $1955)$.

17. "Photoduplication in Libraries." Library Trends 8:3 (Jan. 1960).

18. "Problems of Acquisition for Research Libraries." Library Trends 18:3 (Jan. 1970). 
19. Albert J. Diaz, "Microreproduction Information Sources," Library Resources and Technical Services 11:2 (Spring 1967), p. 211-14.

20. Robert C. Sullivan, "Developments in Photoreproduction of Library Materials, 1970." Library Resources and Technical Services 15:2 (Spring 1971), (In press).

21. Marion O. Boner, "Acquisition of Microforms in Law Libraries." Law Library Journal 63:1 (Feb. 1970), p. 66-69.

22. Micrographic Weekly 1:1 (June 22, 1970), (Los Angeles: Technical Information Inc.).

23. Information and Records Management 5:1 (Jan. 1971), (New York: Badler Group).

24. The Journal of Micrographics 4:2 (Jan. 1971), (Silver Spring, Maryland: National Microfilm Association).

25. Micro-News Bulletin No. 8 (Feb. 1971), (Silver Spring, Maryland: National Microfilm Association).

26. International Micrographic Congress Journal No. 13 (Fourth Quarter 1970). (New York: Information and Records Management).

27. Vernon D. Tate, ed., Proceedings of the Nineteenth Annual Meeting and Convention (Annapolis: National Microfilm Association, 1970). (In press).

28. Hubbard W. Ballou, ed., Guide to Microreproduction Equipment (4th ed.; Annapolis: National Microfilm Association, 1968), $493 \mathrm{p}$.

29. — 1970 Supplement to the Guide to Microreproduction Equipment (Silver Spring: National Microfilm Association, 1970), $247 \mathrm{p}$.

30. Jack Rubin, ed., International Directory of Micrographic Equipment (Saratoga: International Micrographic Congress, 1967), $519 \mathrm{p}$.

31. Donald M. Avedon, ed., Glossary of Terms for Microphotography and Reproductions Made From Micro-Images (Annapolis: National Microfilm Association, 1966). 4th rev. ed. Informational Monograph No. 2. (5th rev. ed. in press).

32. William R. Hawken, Copying Methods Manual (Chicago: American Library Association, 1966). 375 p. (Library Technology Publication No. 11).

33. American Library Association, Library Technology Program, Library Technology Reports (Chicago: American Library Association).

34. Subject Guide to Microforms in Print, 1970-71 (Washington: NRC-Microcard Editions, 1970), 119 p.
35. George A. Schwegmann, Jr., "The Bibliographical Control of Microforms," Library Trends 8:3 (Jan. 1960), p. 380-90.

36. Edmund L. Applebaum, "Implications of the National Register of Microform Masters as Part of a National Preservation Program," Library Resources and Technical Services 9:4 (Fall 1965), p. 489-94.

37. Fred Blum, "The National Register of Microfilm Masters (NRMM)," Microcosm 12:1 (June 1967), p. 3.

38. U. S. Library of Congress, Union Catalog Division, Newspapers on Microfilm. 6th ed., (Washington: Library of Congress, 1967), $487 \mathrm{p}$.

39. U. S. Library of Congress, Microfilm Clearinghouse Bulletin No. 86. June 12, 1969 (Appendix to the Library of Congress Information Bulletin).

40. U. S, Library of Congress, Descriptive Cataloging Division, The National Union Catalog of Manuscript Collections, 1969, and Index 1967-69 (Washington: Library of Congress, 1970), $1082 \mathrm{p}$.

41. U. S. Library of Congress, Manuscript Division, News From the Center. No. 7 (Spring 1970), $46 \mathrm{p}$.

42. Philadelphia Bibliographical Center and Union Library Catalogue, Union List of Microfilms, Cumulation 1949-1959 (Ann Arbor: J. W. Edwards, 1961), Vols. I \& II.

43. Eva Maude Tilton, compiler. Union List of Publications in Opaque Microform (Rev. ed.; New York: Scarecrow Press, 1965).

44. Directory of Institutional Photocopying Services (Including Selected Interlibrary Loan Policies), (Chicago: University of Chicago Library, 1969), 48 p.

45. The National Union Catalog, Pre-1956 Imprints (London: Mansell Information/ Publishing Ltd., 1968).

46. American Library Association. Library Standards for Microfilms Committee. Microfilm Norms (Chicago: American Library Association, 1966), p. 48.

47. Stephen R. Salmon, Specifications for Library of Congress Microfilming (Washington: Library of Congress, 1964), p. 21.

48. U. S. Federal Council for Science and Technology. Committee on Scientific and Technical Information. Federal Microfiche Standards, 3rd ed., 1968. (PB 167-630).

49. Specifications for Microfiches (New York: American National Standards Institute Inc., 1970), 16 p. (PH5.9-1970).

50. Allen B. Veaner, The Evaluation of Micropublications: A Handbook for Librarians (Chicago: American Library Association, Library Technology Program, 1971), 59 p. 